\title{
Becoming (a) public: what the concept of public reveals about a programmatic public pedagogy at the university
}

\author{
Leena Ripatti-Torniainen ${ }^{1}$
}

Published online: 24 August 2017

(C) The Author(s) 2017. This article is an open access publication

\begin{abstract}
This article extends the ongoing argumentation of 'public', publics and universities by providing a conceptual discussion of issues at the core of the public sphere: how does public form and exist amid private and individual life and pursuits, and how does a collective public body identify itself. The discussion is placed in dialogue with two earlier contributions to 'becoming (a) public' by Simons and Masschelein (European Educational Research Journal, 8(2), 204-217, 2009) and Biesta (Social \& Cultural Geography, 13(7), 683-697, 2012). Brought together, these contributions constitute a definition of a programmatic public pedagogy at the university. This article develops the definition of a programmatic public pedagogy by drawing on the conceptual core meanings of public in continental antiquity, Enlightenment and American pragmatism. The author discusses public as (1) indefinitely circulating discourses, (2) sociability between strangers, (3) macro structures and (4) the political public sphere. The article reveals that the 'becoming (a) public' extends and occurs across a broad spectrum, and that the discursive and sociable manifestations of public are not secondary to explicitly political action but have an inherent value in themselves. The article distinguishes the character of public as constant openness to the emergence of what is yet not known from interpretations that locate public in the existing structures, ideologies and forms of action. The dialogue with Simons and Masschelein and Biesta shows that this distinction has critical implications on how programmatic public pedagogy is understood at the university.
\end{abstract}

Keywords Education $\cdot$ Public $\cdot$ Public pedagogy $\cdot$ Public sphere $\cdot$ University

Leena Ripatti-Torniainen

leena.ripatti-torniainen@helsinki.fi

1 Faculty of Social Sciences, University of Helsinki, Unioninkatu 37, P.O. Box 54, FI-00014 Helsinki, Finland 


\section{Introduction}

'Public' and publics remain topical, even urgent concepts for universities. Recently in Higher Education, Carolina Guzmán-Valenzuela (2016, p. 667) grounded her article "Unfolding the meaning of public(s) in universities" by referring to the lack of "an overarching understanding of this field". While scholarly discussion on public(s) and universities is getting increasingly richer, the challenge remains to consider the extensive scope and full potential of the concept that has been reckoned to be among the most influential in the western thought (Weintraub 1997). In this article, I continue to work towards a more comprehensive understanding and discuss the conceptual meanings of 'public' in the context of a question that hits the core of the public sphere (Dewey 1927/2003; Mills 1956/2000; Habermas 1989; Splichal 2010): how 'public' forms and exists amid private and individual life and pursuits, and how a collective public body identifies itself.

I place my paper in dialogue with two earlier contributions (Biesta 2012; Simons and Masschelein 2009). ${ }^{1}$ Both explicitly approach the topic as a question that calls for delicate consideration of what pedagogy and university are for. Biesta (p. 683) defines a programmatic view of public pedagogy that would enact "a concern for the public quality of human togetherness", whereas Simons and Masschelein (p. 204) define a public university that would constitute "a public by gathering people around matters of concern", and make "something a public concern for people".

I observe that Biesta supports significantly Simons and Masschelein's definition of a university in which a public identifies itself, although the former does not use those formulations. Similarly, I find that Simons and Masschelein's approach contributes to Biesta's pedagogically programmatic view on public pedagogy, although Simons and Masschelein do not use Biesta's formulations. Brought together in this article, I collate the authors' arguments under a title of a programmatic public pedagogy at the university. Biesta's contribution is philosophical. Simons and Masschelein write in a slightly more operationalized way and in the more firmly specified context of the university. While all three authors write with great conceptual precision, their approaches remain on a relatively abstract level. In the following, I relate their focused arguments to a more extensive conceptual discussion on meanings and manifestations of public. In this way, I aim at developing their arguments and clarifying the abstract, an inherently ethereal topic.

I first introduce the arguments developed by Biesta and Simons and Masschelein. I then proceed to the heart of my argument and discuss the conceptual premises of public as well as the more cultivated meanings that derive from them. I illustrate the extensive web of arrangements through which cultures and societies manifest and materialize the idea of public. I discuss public as (1) indefinitely circulating discourses, (2) sociability between strangers, (3) macro structures and (4) the political public sphere. Finally, I return to the dialogue with Biesta and Simons and Masschelein and demonstrate how the more extensive conceptual interpretation of public develops their arguments on a programmatic public pedagogy at the university.

The questions of this article are as follows:

1. What are the core conceptual meanings of public?

\footnotetext{
${ }^{1}$ Throughout this paper references to either or both Biesta, and Simons and Masschelein — without a year of publication but possibly with a page reference refer to Biesta (2012) and Simons and Masschelein (2009).
} 
2. What do the conceptual meanings reveal in the context of how public forms and exists, and how a collective public body identifies itself?

3. How does this develop the argument on a programmatic public pedagogy at the university?

\section{Biesta and Simons and Masschelein: what they seem to say}

In his article Becoming public: public pedagogy, citizenship and the public sphere, Gert Biesta (2012) asks what kind of educational work could "reclaim or reinvigorate the public sphere" (p. 683), and provides as the answer a conception of public pedagogy understood as "an educational intervention enacted in the interest of the public quality of spaces and places and the public quality of human togetherness" (p. 684).

Biesta develops a distinctive concept of public pedagogy. The concept has been used in educational scholarship in many ways (Sandlin et al. 2011) that show not only broad diversity but also confusion of what 'public' might mean. Furthermore, the ways scholars have used the concept of public pedagogy stretch 'pedagogy' across a wide spectrum, from socialization to teaching in formal educational institutions (Rantala and Ripatti-Torniainen 2013; Sandlin et al. 2009, 2011). Biesta (pp. 690-693) instead introduces a remarkably more focused definition. He separates three interpretations of what he calls "a more programmatic and more political" interpretation (p. 684) of the concept. Biesta therefore detaches his interpretation from what he regards as less programmatic and less political understandings of public pedagogy, such as the socializing force of popular media and culture. He reserves the concept of public pedagogy to active educational interventions in the public domain. By doing so, Biesta develops the concept of public pedagogy a clear step further.

However, Biesta's achievement is more far-reaching. By founding his conception of the 'becoming public' on Hannah Arendt's (1977) concept on freedom, Biesta (p. 686-690) seizes the conceptual core of public. Arendt's (1977, p. 151) concept is the freedom to "call something into being which didn't exist before". Nevertheless, this calling into being cannot occur in isolation from others. This freedom materializes in the presence of others whom one does not know, and therefore is exposed to their response. In this conceptual sense, action in the public sphere does not refer to excluding action, such as a declaration of homogeneity or commonness or a monologue dissemination of pre-defined truths. Rather, action in the public sphere occurs while acting amid plurality, as a stranger in an always somewhat strange world (Biesta pp. 686-690). 'Becoming public' is therefore making an initiative without knowing how others will respond, and thus being a subject and being subjected to others at the same time. To Biesta, this is the 'public quality' of human togetherness, to which he bonds his proposition of a programmatic public pedagogy.

In his argumentation, Biesta initially introduces (pp. 691-692) and then steps back from the two other interpretations of programmatic public pedagogy that he defines: 'a pedagogy for the public' and 'a pedagogy of the public'. By a pedagogy for the public, he refers to instruction that would aim at teaching the citizenry either implicitly or explicitly to be "for example, lawabiding, tolerant, respectful and active" (p. 691). By a pedagogy of the public, Biesta refers to the democratic processes and practices within which one might learn critical awareness. He notes that political learning "comes with a particular conception of political agency in which (political) action follows from the right, correct or true understanding" (p. 692). He puts both these interpretations aside when developing his argument. 
Biesta's clarity in moving public pedagogy beyond socialization to current state of affairs and beyond learning responsiveness to pre-defined needs resonates well with the approach of Maarten Simons and Jan Masschelein. In the article The public and its university: beyond learning for civic employability? (2009), they argue that a publicly acting collective body forms in the transformation of 'facts' into 'matters of concern'. Simons and Masschelein (pp. 205-211) illustrate their conception by constructing a comparison between the modern university, the entrepreneurial university and what they call the public university. Simons and Masschelein argue that the concept of public at the modern university was based on the understanding of the university as a "self-proclaimed gatekeeper of historical progress and emancipation through cultivation based on reason" (p. 206). Scholars indeed had a public role, but that role was based on authority to orient the uneducated people away from ignorance towards enlightenment. The entrepreneurial university, the authors claim, replaced these modern ideas with the guiding idea of empowerment. Simons and Masschelein argue that empowerment appears at the entrepreneurial university without historical self-understanding and thus without orientation into future "beyond what is needed or available in a competitive environment" (p. 209). They further argue that public relevance of scholarship can materialize at the entrepreneurial university only through innovation, i.e. by responsiveness to the current "matters of need" (Simons and Masschelein, p. 211).

Simons and Masschelein argue that both the modern university and the entrepreneurial university detach and immunize students and scholars by emphasizing either facts or responsiveness to currently existing needs. The alternative the authors develop seizes the core of public in a similar manner as Biesta did. While Biesta (pp. 686-690) seized public as action that calls something new into being yet is dependent on the response of others, Simons and Masschelein (pp. 211-213) highlight, first, the orientation into what is not yet known and, second, the identification of issues as concerns that bring strangers together to act in the face of the yet unknown.

Drawing on the classic concept of John Dewey (1927) and contributions by Latour (2005) and Marres (2005), Simons and Masschelein argue that the university should emphasize "matters of concern" that are issues "for which no solution is available" by "the given order of the society", by the existing private and official institutions and experts (p. 212). Transforming issues in university teaching into matters of concern would expose students to being attached and communized, i.e. exposed to "how to live together in the face of complicated issues" (Simons and Masschelein, p. 213). Compared to Biesta's approach on how public becomes and occurs in distinctive quality of human togetherness, Simons and Masschelein (p. 214) operationalize the phenomenon into matters of concern that can initiate "people and things" to come into being as an acting, collective body - a public.

Both Biesta and Simons and Masschelein construct juxtapositions in their argumentation, highlighting that education has the capacity to contribute to the 'becoming public' and 'becoming of a public' but also the capacity to prevent it. Biesta (pp. 691-692) argues that the pedagogies of instruction and facilitation of learning prevent public quality in which freedom could appear. Similarly, Simons and Masschelein (p. 207) argue that both the modern and the entrepreneurial university prevent a public from coming into being. All authors seem to suggest that radical re-conceptualizations of pedagogy and the role of the university respectively are needed.

How this could be achieved remains at a relatively abstract level. Biesta (pp. 693-694) suggests "interventions" and "interruptions" that are not based on the educator's knowledge nor on facilitation of learning. His suggestion for educational work is to "keep open the 
opportunities for becoming public" (Biesta, p. 693). Simons and Masschelein (p. 214) suggest that the university should link research and teaching in "very specific practices that actually gather humans and things, students and research objects, and constitute a local public exposed to matters of concern". By transforming "matters of fact into matters of concern", such practices expose students to things "instead of teaching them facts or being responsive to their needs and the needs of society" (Simons and Masschelein, p. 213).

I argue that the extensive concept of public itself clarifies and helps to develop the suggestions that Biesta as well as Simons and Masschelein have made. In the following section, I aim at a rather comprehensive conception by drawing from the conceptual core meanings of public in continental antiquity, the Enlightenment and American pragmatism.

\section{Public: two plus four conceptual meanings}

At the simplest level, the characteristics of public derive from the basic meanings to which the concept can be reduced. Several concept analysts write about them, yet refer to them with slightly varying vocabulary. I call the first meaning accessibility and the second meaning collective. Scholars refer to accessibility as visibility or audibility (Arendt 1958, p. 50; Weintraub 1997, p. 7), and as openness or availability (Price 1992, p. 7). Scholars refer to collective when they define public as issues that affect a number of individuals rather than only one individual (Weintraub 1997, p. 7), or as issues that "transcend the particular and private experience of individuals, however they identify themselves" (Cayton 2008, pp. 3-4). Laursen (1996, p. 254) reports how the double definition of accessibility and collective already existed in the classical period Latin, containing the two meanings of, first, anything "out in the open, not in one's to house", and second, of the state, and anything "of general effect and use in society". Hannah Arendt (1958, p. 52) defines the concept of public as that which "signifies the world itself, in so far as it is common to all of us and distinguished from our privately own place in it".

More cultivated meanings derive from these conceptual premises, illustrating the extensive arrangements through which cultures and societies illuminate and materialize the ideas of accessibility and collective. In the following sub-sections, I discuss four meanings: public as (1) indefinitely circulating discourses, (2) sociability between strangers, (3) macro structures and (4) the political public sphere.

These meanings bring forth the idea that I have already discussed while referring to Biesta as well as Simons and Masschelein: public deals essentially with conditions, in which an individual life is exposed to the presence and actions of other human beings. Public conditions and arrangements come between our subjective and intersubjective existence. As Alan Wolfe (1997) observes, these conditions push us to move between our sole individual being and social conditions and pursuits of life. Instead of fixing my analysis on the oft repeated antithesis between private and public, which Jeff Weintraub (1997) calls "the grand dichotomy" of western thought, I will in the following sub-sections illuminate manifestations of public as intermediary practices, in the midst of which an individual constantly moves between these analytical opposites. All four following meanings illustrate that movement.

Public as indefinitely circulating discourses First of all, public is manifested in social and cultural practices that enable the communication of meanings (Cayton 2008, pp. 1, 22-23). Language and literacy are prime examples of resources that enable collective identification of 
meanings, without which it would be impossible to communicate and reach any understanding between individuals (Mead 1934/2015, pp. 75-77, 89-90; Cayton 2008, p. 23). Public is in this sense a discursive phenomenon and materializes as discourses that a collective body of human beings identifies (Warner 2002, p. 413). To identify a discourse is not equivalent to agreeing on the meanings of the discourse. Furthermore, public does not refer to cultural descent or group membership. Instead, in this discursive sense, being part of a public refers to the ability to understand and address discourses. Warner (2002) writes about the indefinite circulation of texts, in which public exists.

Cultural texts enjoy an esteemed place in the scholarly history of the public sphere. The reading and writing public (Kant 1784/1996) and the literary public (Habermas 1989) are among the classic conceptualizations referring to the abilities of independent judgement and the subsequent awareness of societal and political standing. Jürgen Habermas (1989) considers the beginning of the modern public sphere to be the clubs that gathered to discuss cultural events. He conceives that cultural abilities produced political abilities as the bourgeoisie public sphere developed (2004, pp. 57-61). Raymond Williams (1958)/1987 makes an even stronger point by arguing that culture, instead of the political public sphere, would be the primary manifestation of democracy. John Dewey (1915/2003, p. 39) declares culture to be "the democratic password".

The connection between the writings of Dewey, Williams and Habermas is that all three consider culture to be integral not only to any notion of public but also to any notion of political public sphere. The relevance of culture, especially when understood as the way of living (Williams 1958/1987), lies in its ability to initiate enough commonalities between individuals who would otherwise be complete strangers to each other or who would never meet face to face.

The political character of culture is evident here. Scannell (2007, pp. 95-103) reports "the deeply political de-politicization of culture" in post-World War I UK, which led to the establishment of English literature as an academic subject. The new subject, to be taught in schools, would make available the treasures of literature to everyone, instead of having previously rather been the possession of the elite classes, and would create a sense of community among the war-torn nation (Scannell 2007, pp. 97-98). As the century unfolded, this project was complicated and the canonized culture questioned, with the subsequent recognition of marginalized cultures (Nieminen 1997; Scannell 2007, pp. 103-117). The idea of cultural texts, discourses, symbols and codes whose acquaintance serves as the basis for the further communication and elaboration of meanings has nevertheless maintained its relevance (Warner 2002, p. 420; Jordan 2005; Cayton 2008, pp. 1-3, 22-25).

To conclude, social and cultural discourses enhance the basic meanings of publicaccessibility and collective - by presenting themselves as permeable practices, enabling individuals to identify and address issues and join in collective processes (Mead 1934/2015; Cayton 2008). The indefinite circulation of discourses enables the constantly ongoing and uncontrollable re-interpretations and re-negotiations of previously established meanings. I consider that public in this discursive sense refers to a necessary condition for the goals of both Biesta and Simons and Masschelein. The condition is the identification of denominators that make issues "discussable in nonpersonal terms and not only within the particular lifeworlds of individual subjects involved in them" (Cayton 2008, p. 20; see also Dewey $1927 / 2003$, p. 322), thus enabling collective proceedings such as public discourse.

Public as sociability between strangers Public understood as sociability between strangers adds significant dimensions to the meanings of public. The realm of sociability emphasizes 
social conventions that enable everyday encounters with people one does not know (Weintraub 1997, pp. 16-27). While public as circulating discourses already involves the idea of an indefinite number of participants in the discursive space, public understood as sociability inserts spatial and aesthetic spaces. Sociability illustrates that public does not only refer to discursive gathering but also to dwelling physically in the unfamiliarity and diversity that is present in public spaces.

Jeff Weintraub (1997) remarks that the pulse of two cities, Athens and Babylon, is felt in the conceptual history of public: polis and cosmopolis. Weintraub (ibid.) argues that, since the dawn of the modern period, western thought has emphasized only polis: public life being conceived as the materialization of citizenship, i.e. conscious collective action and deliberation. This emphasis has cast a shadow over another historically influential understanding of public life: that of diverse sociability labelled by tolerance without a presumption of a selflegislative community, illustrated so well by a street of a cosmopolitan city (ibid., pp. 25-27). Weintraub ensures that his reader comprehends this cosmopolis is not "the Stoic or Kantian sense of the ideal unity of mankind" (ibid., p. 26) but rather the celebration of the lively and unplanned co-existence of heterogeneous groups, rich symbolic display and the simultaneous distance and close physical proximity between strangers. This is public in urban, currently increasing, digital space.

Some interpretations of public pedagogy (e.g. Giroux 1988, 2001) and cultural pedagogy (e.g. Wright and Maton 2004) have highlighted the profoundly political, disempowering and discriminating character of media-saturated public space or the prospects of using the cultural and geographic spaces in learning citizenship (e.g. Wildemeersch 2012). Such considerations bring the sociable meaning of public immediately to the political terrain of power. While these approaches are necessary, the social meaning of public also deserves serious consideration without being immediately subordinated to a political topic. Billions of city inhabitants spend their lives in daily encounters with unfamiliarity. They not only survive but often make themselves comfortable and, without any obligation, create passing moments of convenience and solidarity, for example, through short friendly verbal exchange and considerate behaviour that recognizes the presence of other persons in the common space. This willingness to dwell in the midst of ever-expanding diversity and to contribute to peaceful coexistence between strangers illuminates the conceptual root meanings of public: accessibility and collective.

Public, understood as sociability between strangers, surrounds us as a condition we can never entirely control and in which we continuously expose ourselves to unexpected encounters and events. Public as sociability emphasizes in powerful ways Biesta's argument that public is about plurality instead of commonality or a homogeneous community.

Public as macro structures Public in the meaning of authority and macro structures is one of the major sources of the bewilderment that surrounds the concept, and thus necessary to discuss in this article. The reason for the perplexity is the fine line between public and private that actualizes itself in political and economic ideologies in distinct ways (Cayton 2008; Weintraub 1997; Wolfe 1997), and receives its most explicit manifestations in the macro structures of a society.

By macro structures, I refer to fields like law, which grants rights and prescribes obligations to citizens, and government activities and policies that regulate extensive areas of life in issues such as taxation, social security, health care and education. Features peculiar to each political 
culture escalate these distinctions, leading to a complex variety of combinations of public and private across the globe. Liberalism that values the initiatives from the private realm reserves a considerably narrower scope for public authorities than the opposite ideologies, in which the state is perceived as the collective subject (Cayton 2008, pp. 4-7). At the same time, other macro actors, such as religion in some cultures, or private companies that run important services and sustain infrastructure may gain significant influence alongside less powerful government authorities. Alan Wolfe (1997, p. 182) remarks that the division between public and private is in its all complexities necessary not only to understand societies but also to perceive how they could be improved.

In the context of accessibility and collective, the macro structural meaning of public primarily refers to arrangements that bind the entirety of the collective group, such as all the citizens of a nation state. The rationale, by which the line between public and private is defined, regulates the relations between individuals, like family members, or employees and employers. Furthermore, the rationale regulates the relations between an individual and the authorities in issues such as what is regarded as "domestic", the extent to which authorities bear responsibility over enabling access, such as securing individual life prospects, and how extensive income transfers are imposed from wealthier to less fortunate groups. In this way, the macro structures reveal which issues have been identified and approved as collective as opposed to being merely private.

The collective denominators of any issue, the recognition and re-negotiations of which occur through the discursive manifestations of public, are thus reflected at the macro structural level. The scholarship produced on the increasingly contested public character of universities (e.g. Marginson 2007, 2011; Biesta 2009; Pusser 2012) relates thus not only to macro structural and political meanings of public but also to the discursive meaning.

Scholars occasionally present authority and macro structures, particularly the state, as the primary meaning of public. There are historical reasons for the longevity of such a concept. Laursen (1996, pp. 253-255) and Weintraub (1997, pp. 10-16) demonstrate how the concept of public narrowed in Europe towards the eighteenth century. The concept gained the meaning of the state: the sovereign that rules through jurisdiction and dominance (Ozouf 1988; Weintraub 1997, pp. 10-16). As we still today occasionally reduce the meanings of public primarily to the state, for example, by conceiving public in education as a question of stateprovided education, we reflect this historical concept. It is important to recognize that the concept of public as a state strengthened in the early modern period of Europe at the expense of the agency and judgement-related meaning of public. This particular meaning of public reveals a counterforce to the state or other ruling authority. It is to this essential meaning that I now turn.

Public as political public sphere Citizenry that is aware of its political potential and capable of judgement constitutes the primary meaning of public both in classical antiquity and in the Enlightenment. Both periods cherished the public realm and esteemed the philosophical and political ideal of citizens' self-governance and political liberty in the public sphere as the highest pursuits of human life (Arendt 1958; Kant 1784/1996; Held 2006, pp. 11-55). Public political life had a deeper meaning than citizens in mature democracies and welfare states now recognize. Hannah Arendt (1958) clarifies that while an individual of classical antiquity was in the private realm of household tied in many ways to biological and material realities, the public realm of polis was the realm of autonomy and liberty - for those who were 
entitled to it. Public life represented life that extended beyond the limitations of biological human life. Arendt (1958) illustrates that the distinction of the private and public realms was so profound that access to public life was considered to be another life altogether (Arendt 1958, pp. 36-37).

At the dawn of modern education and nation states, the Enlightenment philosophy considered the public realm as the medium for individual as well as societal transformation (Kant 1784/1996; Laursen 1996; Schmidt 1996). Immanuel Kant's (1784/1996) renowned essay "What is Enlightenment" contributed to the contemporary discussion that concerned the burdensome progress of Enlightenment despite the new formal rights (Schmidt 1996, p. 3). In the essay, Kant $(1784 / 1996$, p. 47) presents the newly liberated public realm, more specifically the public use of reason, as the method of "mankind's exit from its self-incurred immaturity". Indeed, Kant (1784/1996) gives a profound meaning to action in the public realm by clarifying that individuals can execute their freedom, i.e. their ability to self-legislate, by acting autonomously upon their judgement in the role of a member of humanity and in the widest possible manner among their peers (ibid.). In the midst of societal and cultural shifts and consequent social alienation, the public realm enabled new self-world relationships regardless of the far more limited spaces of, for example, family or the occupational realms (Kant 1784/1996, p. 47).

Compared to the other core meanings of public that I have addressed above, the political public sphere refers most strongly to consciously practiced action. The qualifications found, for example, in Kant's (1784/1996) fundamental essay, are that citizens are aware of their political potential, constitute a public counterforce to the ruling authority through conscious action and are capable of judgement in public. Laursen (1996, pp. 257-258) points out that Kant (1784/1996) drew a clear distinction between public political action and activities in other areas of life. Similarly, Arendt (1958) stresses that citizenship in the classical period polis meant an ability to move across the then sharply distinguished realms of private and public life. Wolfe (1997) observes that Arendt (1958, p. 33) wanted to illustrate that such a boundary does not apply to modern societies that rather organize intermediary processes between the extreme ends of private and public. What I regard as educationally essential to preserve in the idea of moving across different realms is the ability in the individual to act in the political public realm if needs be, even though the explicitly political public action would only really happen occasionally during life.

A whole range of definitions of desirable courses of action has been introduced and rationalized in political philosophies for public political agency. In his synthesis of democracy, David Held (2006) demonstrates that a concept of man is included in every model of democracy. Furthermore, the concepts vary considerably across different models. For example, republicanism emphasizes civic virtue while deliberative democracy perceives political action as intersubjective endeavour (ibid.) In brief, while republicanism emphasizes virtuously acting citizens who willingly make the moral choice of rationalizing public issues under solidarity, equality and justice, the procedures of deliberation conceive the rationality as an intersubjective, discursive proceeding (Weintraub 1997, pp. 10-16; Held 2006, pp. 29-55, 231-255; Honneth 2007, pp. $218-$ 221; Cayton 2008, pp. 10-14).

I find that, to fully understand the argument on the public quality of human togetherness (Biesta) and that on the gathering of a public (Simons and Masschelein), it is first necessary to be aware of the diverse but dense definitions for desirable public action in political 
philosophies, theories and ideologies. There is a distinctive agent in the scholarly history, that of the public, through which scholars illuminate the delicacy of the political public agency. Although being occasionally and misleadingly used as a synonym of citizenry, the public is not primarily defined by its state-granted rights. Instead, the public is defined by its qualities: by its own awareness of its political potential and its intention to consciously claim political influence through public action (Splichal 2010; Malmberg 2012).

For example, in their classic sociological categorizations at the beginning of the twentieth century, Robert E. Park (1904/2010) and Herbert Blumer (1946/1999) separated the public from other types of collective action, such as a crowd (Park 1904/2010) or a mass or several types of crowds (Blumer 1946/1999). The mass, the crowd and the public all form spontaneously between strangers, hence illuminating one central condition of public discussed earlier in this article. The public is, as the antonym of other types, characterized by the identification of a collective problem, which the public consciously orients to solve through discourse by orienting towards open-ended interactive relations with an unrestricted number of participants (Park 1904/2010, pp. 83-94; Blumer 1999, pp. 14-23). The method of the public is thus public discourse, along which the public gradually proceeds towards tentative public opinion (Splichal 2010; Malmberg 2012).

However, the definitions and desired qualities of the public are not necessarily free from biases regarding political concepts and ideologies. Influential readings of the public (e.g. Pietilä 2001; Splichal 2010) have for example emphasized issue-centred, rational, argumentative public debates. In their emphasis on issues and matters of concern, around which a public gathers, Simons and Masschelein could be read to represent this hierarchical interpretation, in which the desirable issue-centred, rational and argumentative forms of public action are placed higher and assumed to be achievable to fewer individuals (Price 1992; see Young 2000, pp. 56-57).

\section{What do the conceptual meanings reveal about 'becoming (a) public'?}

I have so far analysed the core conceptual meanings of public and discussed discursive, sociable, macro structural and political manifestations of this influential concept. The conceptual discussion above has provided the answer to the first question of this article. In this section, I proceed to the second question and show what the rather extensive conceptual discussion reveals about the topic that Biesta as well as Simons and Masschelein explore: how public forms and exists amid private and individual lives and pursuits, and how a collective public body identifies itself.

The conceptual meanings of public reveal, first, that the 'becoming (a) public' extends across a broad spectrum, from dwelling among and communicating with others to conscious political action that claims to change authorities and structures. Second, the conceptual discussion above shows that all other meanings and manifestations of public come together in the political public sphere. Without discursive and sociable manifestations of public, the political public sphere would be shallow and literally meaningless. While the realm of macro structures in many countries guarantees a rich variety of public scopes for action to individuals, including constitutional rights, those roles would not have been achieved, nor would they be redeemed or extended without consciously practiced political action.

The relevance of an extensive interpretation of the 'becoming (a) public' is illuminated by John Dewey who, in his eminent work The Public and Its Problems (1927/2003), asks why the public - the body of citizens aware of their political influence and willing to use their 
abilities - is "in eclipse" (2003, 308). Dewey's objective is to examine how a politically capable body could appear-how the public could find itself and organize its actions (ibid., p. 328). Dewey therefore analyses Simons and Masschelein's topic. While Dewey's objective can be located in the political public sphere, the relevance for my extensive conceptual approach lies in the conditions under which Dewey (1915/2003, 1927/2003) considers the public can emerge in the political sense.

Dewey (1927/2003) argues for the necessity of exposing oneself to the extensive manifestations of public, for rich and lively give-and-take between individuals and groups. The public cannot find itself unless there are mutually understood meanings (ibid., p. 331), unless there appears "a common denominator among all the shifting and unstable relationships" (ibid., p. 322). He comments that all meanings are socially transmitted (ibid., p. 330), which makes meanings attainable only in communication. He stands up for diverse encounters with the world. Dewey (1915/2003, 1927/2003) thus names fields to which I have referred to as circulating discourses and sociability between strangers. John Dewey's (ibid., pp. 351-373) enduring insight is that the collective political body identifies itself through relations that stretch beyond the mere political public sphere, to which Axel Honneth (2007) refers in his significant analysis. Honneth (ibid.) demonstrates that the crux of Dewey's (1915/2003, 1927/ 2003) thinking is that his concept of the political public synthetizes the pre-political relationality with procedural problem solving in the public sphere.

The conceptual meanings of public reveal that the seemingly non-political discursive and sociable manifestations of public are not secondary to explicit political public action but have an inherent value themselves. Public and its political prospect emerge constantly anew across the whole spectrum that the conceptual discussion has revealed. While both Biesta and Simons and Masschelein argue that pedagogy and the university respectively can prevent public and a public from coming into being, I find it is relevant to stress that the extensive and constantly renewable and re-negotiated manifestations of public can never be entirely controlled by pedagogues, universities or any other actors or institutions.

However, the arguments by Biesta and Simons and Masschelein relate to their aims at defining the special contribution that education could give to the topic of 'becoming (a) public'. I conclude this article by demonstrating how my rather extensive conceptual approach develops their arguments. The following, concluding section provides the answer to the third, final question of this article by separating three contributions to the concept of a programmatic public pedagogy at the university.

\section{How does the approach of this article develop the concept of a programmatic public pedagogy at the university?}

This article develops the concept of a programmatic public pedagogy by revealing, first, the extensive scope and layered character of 'becoming (a) public'. The conceptual discussion above clarifies that Biesta's approach relates to discursive, sociable and the political public sphere meanings and manifestations of public, and that his emphases on plurality and action in the presence of strangers illustrate the significance of exposure to rich manifestations of public. Further, my conceptual discussion shows that Simons and Masschelein's approach relates especially to the political public sphere. Their focus on the emergence of a publicly acting collective body resonates with the scholarly tradition of the forming public (see e.g. Park 1904/2010; Blumer 1946/1999; Dewey 1927/2003; Mills 1956; Splichal 2010). Compared to Simons and Masschelein, Biesta’s (p. 
694) concept of pedagogy "that can be politically significant" implicitly covers also the political significance of seemingly non-political discursive and sociable action.

By providing a rather comprehensive conceptual discussion of public, this article thus clarifies that Simons and Masschelein, in their quest for a public that gathers around matters of concern, emphasize the culmination of what could be conceived as more extensive and gradual processes. Similarly, Biesta in his quest for the public quality of human togetherness emphasizes the conditions from which Simons and Masschelein's collective public agent could emerge. The conceptual discussion demonstrates that a programmatic public pedagogy at the university cannot be reduced to a question of explicit political action. Rather, public pedagogy gains political significance across the whole spectrum of manifestations of public.

Second, this article develops Biesta's and Simons and Massachelein's arguments by providing an operationalization of what a programmatic public pedagogy could mean at the university. While Biesta (p. 693) proposes that educational work would "keep open the possibility for becoming public" and Simons and Masschelein (p. 213) propose that the university would provide "exposures for the public to gather", the conceptual meanings discussed in this article suggest the aspects that educational work would keep open, and to which the university would provide exposure. The first aspect comprises widening meanings and meaning-making, including those that interrupt our established being. The second comprises widening relations, including relations with strangers and relations in which we become strangers. The third comprises action in the presence and dependently on the response of others. The fourth and last, which threads through the other three aspects, is the collective recognition, reinterpretation and renegotiation of denominators around which the public agency could begin to form in the explicit political sense.

This operationalization is a more detailed one and derives from a more extensive conceptual discussion than the suggestions provided by Biesta and Simons and Masschelein. However, many university pedagogues would probably wish to see more detailed suggestions. My omission to do so is a conscious choice, and leads to the third and final contribution I provide.

This article develops the concept of a programmatic public pedagogy by demonstrating that a pedagogically relevant analytical distinction can be identified across all conceptual meanings and manifestations of public. In the conceptual discussion above, I have distinguished the constantly emergent prospect of public from interpretations that locate public in the existing collective structures, ideas, ideologies and forms of action, including those that are regarded as desirable. All meanings and manifestations of public - discursive, sociable, macro structural and political — could be used pedagogically for purposes that Biesta (pp. 691-692) puts aside: as a pedagogy for the public or a pedagogy of the public. By such pedagogies, Biesta refers to instruction that would aim at teaching the citizenry either implicitly or explicitly to be "for example, law-abiding, tolerant, respectful and active" (p. 691), and to democratic processes and practices within which one might learn critical awareness under "particular conception of political agency in which (political) action follows from the right, correct or true understanding” (p. 692). Elsewhere Biesta (2013) analyses areas of educational work and separates qualification and socialization areas. In such qualifying and socializing sense, a programmatic approach of public pedagogy would qualify and socialize students to the established forms of the public domain. That approach would still illustrate the basic conceptual premises of public by providing access to the collective life in a society.

However, the approach of this article has revealed that the meanings of public refer essentially to the transcendence of the established order and established ways of being. In this interpretation, a programmatic public pedagogy refers rather to what Biesta (2013, pp. 4, 
17-24) elsewhere calls the subjectification area of education: emergent ways of being "that are not entirely determined by existing orders and traditions" (ibid., p. 18, see also Biesta 2007, pp. 764-765). My reading of both Biesta as well as Simons and Masschelein is that they argue for such, always emergent public pedagogy as they find the locus of 'becoming (a) public' primarily in public itself, but argue that pedagogy and the university should keep that 'becoming' open and expose students and teachers to public.

The dialogue I established with Biesta and Simons and Masschelein shows that this analytical distinction has critical implications on how public pedagogy is understood at the university. Both Biesta and Simons and Masschelein are alarmed by conceptions that reserve merely a responsive role to public pedagogy and the public role of the university. Biesta (pp. 691-692) writes about approaches of public pedagogy that prepare future citizens to fulfil predefined social, ideological or political aims. Simons and Masschelein (pp. 205-211) write about those public roles of the university that involve definitions which political or economic aims the university should serve. While Biesta and Simons and Masschelein seem here to refer especially to what I have called as the macro structural manifestations of public, the conceptual discussion in this article shows how easily all manifestations of public gain definitions or even pre-defined requirements on the desired behaviour or course of action. Narrowing the definition of a programmatic public pedagogy merely to the qualifying and socializing functions of education would ignore the greatest conceptual prospect of public: continuous openness to the emergence of what is not yet known.

As conclusions for further research, I recommend that this emergence, this reinvigoration of the public sphere, which occurs constantly across the whole wide spectrum I have discussed in this article, would be analysed in the context of the subjectification area (Biesta 2013) of university education.

Open Access This article is distributed under the terms of the Creative Commons Attribution 4.0 International License (http://creativecommons.org/licenses/by/4.0/), which permits unrestricted use, distribution, and reproduction in any medium, provided you give appropriate credit to the original author(s) and the source, provide a link to the Creative Commons license, and indicate if changes were made.

\section{References}

Arendt, H. (1958). The human condition. Chicago: University of Chicago Press.

Arendt, H. (1977). Between past and future: eight exercises in political thought. Harmondsworth: Penguin Books.

Biesta, G (2007). Education and the democratic person: towards a political conception of democratic education. Teachers College Record, 109(3), 740-769.

Biesta, G. (2009). What kind of citizenship for European higher education? Beyond the competent active citizen. European Educational Research Journal, 8(2), 146-158.

Biesta, G. (2012). Becoming public: public pedagogy, citizenship and the public sphere. Social \& Cultural Geography, 13(7), 683-697.

Biesta, G. (2013). The beautiful risk of education. Boulder: Paradigm.

Blumer, H. (1999/1946). Joukko, massa ja julkiso [The crowd, the mass and the public]. Tiedotustutkimus, 22(3) 14-26.

Cayton, M. K. (2008). What is public culture? Agency and contested meaning in American culture-an introduction. In M. S. Shaffer (Ed.), Public culture: diversity, democracy, and community in the United States (pp. 1-25). Philadelphia: University of Pennsylvania Press.

Dewey, J. (1915/2003). The school and society. In L. A. Hickman (Ed.), The middle works of John Dewey, 18991924, Vol 1 (electronic ed.). Charlottesville: InteLex.

Dewey, J. (1927/2003). The public and its problems: an essay in political inquiry. In L. A. Hickman (Ed.), The later works of John Dewey, 1925-1953, Vol 2 (electronic ed.). Charlottesville: InteLex. 
Giroux, H. A. (1988). Schooling and the struggle for public life: critical pedagogy in the modern age. Minneapolis: University of Minnesota Press.

Giroux, H. (2001). Public spaces, private lives: beyond the culture of cynicism. Lanham: Rowman \& Littlefield.

Guzmán-Valenzuela, C. (2016). Unfolding the meanings of public(s) in universities: toward the transformative university. Higher Education, 71, 667-679.

Habermas, J. (1989). The structural transformation of the public sphere: an inquiry into a category of bourgeois society. Cambridge: Polity Press.

Held, D. (2006). Models of democracy (3rd revised ed.). Stanford: Stanford University Press.

Honneth, A. (2007). Disrespect: the normative foundations of critical theory. Cambridge: Polity.

Jordan, J. (2005). Dell Hymes, Kenneth Burke's "identification," and the birth of sociolinguistics. Rhetoric Review, 24(3), 264-279.

Kant, I. (1784/1996). An answer to the question: what is Enlightenment? In J. Schmidt (Ed.), What is Enlightenment? Eighteen-century answers and twentieth-century questions (pp. 47-51). Berkeley: University of California Press.

Laursen, J. C. (1996). The subversive Kant: the vocabulary of "public" and "publicity". In J. Schmidt (Ed.), What is Enlightenment? Eighteen-century answers and twentieth-century questions (pp. 253-269). Berkeley: University of California Press.

Latour, B. (2005). From Realpolitik to Dingpolitik or how to make things public. In B. Latour \& P. Weibel (Eds.), Making things public: atmospheres of democracy (pp. 14-41). Karlsruhe: Centre for Art and Media \& MIT Press.

Malmberg, T. (2012). Yleinen mielipide, viestintä ja kansanvalta: Liberaalista deliberatiiviseen demokratiaan. [Public opinion, communication and democracy: From liberal to deliberative democracy]. In K. Karppinen \& J. Matikainen (Eds.), Julkisuus ja demokratia [The public sphere and democracy] (pp. 15-36). Tampere: Vastapaino.

Marginson, S. (2007). The public/private divide in higher education: a global revision. Higher Education, 53, 307-333.

Marginson, S. (2011). Higher education and public good. Higher Education Quarterly, 65(4), 411-433.

Marres, N. (2005). Issues spark a public into being: a key but often forgotten point of the Lippmann-Dewey debate. In B. Latour \& P. Weibel (Eds.), Making things public: atmospheres of democracy (pp. 208-217). Karlsruhe: Centre for Art and Media \& MIT Press.

Mead, G. H. (1934/2015). Mind, self and society. The definitive edition. Edited by Charles W. Morris. Chicago: University of Chicago Press.

Mills, C. W. (1956/2000). The power elite. Oxford: Oxford University Press.

Nieminen, H. (1997). Communication and democracy: Habermas, Williams and the British case. Helsinki: Suomalainen tiedeakatemia.

Ozouf, M. (1988). "Public opinion" at the end of the old regime. The Journal of Modern History, 60(Supplement: Rethinking French Politics in 1788), S1-S21.

Park, R. E. (1904/2010). Joukko ja julkiso [The crowd and the public]. In V. Pietilä \& Julkisuuspiiri (Ed.), Julkisot, yleisöt ja media [Publics, audiences and the media] (pp. 77-94). Tampere: Tampere University Press.

Pietilä, V. (2001). Reflections on public discussion in the mass media. Nordicom Review, 22(1), 11-21.

Price, V. (1992). Communication concepts 4: public opinion. Newbury Park: Sage.

Pusser, B. (2012). Power and authority in a creation of the public sphere through higher education. In B. Pusser (Ed.), Universities and the public sphere: Knowledge creation and the state building in the era of globalization (pp. 27-46). New York: Taylor \& Francis.

Rantala, L., \& Ripatti-Torniainen, L. (2013). Julkinen pedagogiikka - käsitteenmäärittelyä ja ilmiökentän hahmotusta. [Public pedagogy-specifying the concept and phenomenon in the Finnish context.] Kasvatus, 44(1), 7-16.

Sandlin, J. A., O’Malley, M. P., \& Burdick, J. (2011). Mapping the complexity of public pedagogy scholarship: 1894-2010. Review of Educational Research, 81(3), 338-375.

Sandlin, J. A., Schultz, B. D., \& Burdick, J. (2009). Handbook of public pedagogy: education and learning beyond schooling. New York: Routledge.

Scannell, P. (2007). Media and communication. London: Sage.

Schmidt, J. (1996). Introduction: what is Enlightenment? A question, its context, and some consequences. In J. Schmidt (Ed.), What is Enlightenment? Eighteen-century answers and twentieth-century questions (pp. 144). Berkeley: University of California Press.

Simons, M., \& Masschelein, J. (2009). The public and its university: beyond learning for civic employability? European Educational Research Journal, 8(2), 204-217.

Splichal, S. (2010). Eclipse of "the public": from the public to the (transnational) public sphere: Conceptual shifts in the twentieth century. In H. Moe \& J. Gripsrud (Eds.), The digital public sphere: challenges for media policy. Göteborg: Nordicom.

Warner, M. (2002). Publics and counterpublics. The Quarterly Journal of Speech, 88(4), 413-425. 
Weintraub, J. (1997). The theory and politics of the public/private distinction. In J. Weintraub \& K. Kumar (Eds.), Public and private in thought and practice: perspectives on a grand dichotomy (pp. 1-42). Chicago: University of Chicago Press.

Wildemeersch, D. (2012). Imagining pedagogy in public space: visions of cultural policies and practices in a city in transformation. International Journal of Lifelong Education, 31(1), 77-95.

Williams, R. (1958/1987). Culture and society: Coleridge to Orwell. London: Hogarth Press.

Wolfe, A. (1997). Public and private in theory and practice: some implications of an uncertain boundary. In J. Weintraub \& K. Kumar (Eds.), Public and private in thought and practice: perspectives on a grand dichotomy (pp. 182-203). Chicago: University of Chicago Press.

Wright, H. K., \& Maton, K. (2004). Cultural studies and education: from Birmingham origin to glocal presence. The Review of Education, Pedagogy and Cultural Studies, 26, 73-89.

Young, I. M. (2000). Inclusion and democracy. Oxford: Oxford University Press. 